\title{
COMPARATIVE REFLECTIONS ON THE VINDICATION OF RIGHTS IN
}

BRAZIL ${ }^{1}$

\section{REFLEXÕES COMPARADAS SOBRE A REIVINDICAÇÃO DE DIREITOS NO BRASIL}

\author{
Ángel R. Oquendo
}

George J. and Helen M. England Professor of Law, University of Connecticut; CAPES Visiting Professor from Abroad, Federal and State Universities of Rio de Janeiro; DAAD Visiting Professor, Free University of Berlin, Germany. Ph.D., M.A. (Philosophy), A.B. (Economics and Philosophy), Harvard University; J.D., Yale Law School. Connecticut, United States of America. E-mail: oquendo@zedat.fu-berlin.de

\begin{abstract}
The present work examines the contrast between the vindication of rights in Brazil and the other countries in the Americas, especially with regard to the writ of security and analogous devices. It scrutinizes the historical development, along with points of convergence and divergence. Furthermore, the discussion contemplates legislation, doctrine, and the caselaw. Thereby, it purports to analyze admissibility, meritoriousness, appealability, preclusion, stare decisis, and the requirement of state action.
\end{abstract}

KEYWORDS: Comparative law. Civil procedure. Constitution. Writ of security. Writ of protection. Summary judgment. Temporary restraining order. Habeas corpus. Unconstitutionality suits. Vindication of rights. Legislation. Doctrine. Caselaw. Res judicata. Appeal. State action. Argentina. Brazil. Mexico. Paraguay. United States.

RESUMO: O presente trabalho examina o contraste entre a reivindicação de direitos no Brasil e outros países das Américas, especialmente à vista do mandado de segurança e outros meios análogos. O trabalho perquire o desenvolvimento histórico, destacando pontos de

\footnotetext{
${ }^{1}$ Recebido em 28/03/2021, sob dispensa de revisão.
} 
convergência e divergência. Além disso, a discussão contempla a legislação, a doutrina e a jurisprudência. Dessa forma, o estudo se propõe a analisar a admissibilidade, o mérito, a recorribilidade, a preclusão, a coisa julgada e a necessidade de ação do estado.

PALAVRAS-ChAVE: Direito comparado. Processo Civil. Constituição. Mandado de segurança. Julgamento sumário. Tutela inibitória temporária. Habeas Corpus. Ações de inconstitucionalidade. Reivindicação de direitos. Legislação. Doutrina. Jurisprudência Coisa julgada. Recurso. Ação do estado. Brasil. México. Paraguai. Estados Unidos.

In contrast to their fellow Iberian Americans, Brazilians benefit from a writ of security, not protection. The former of these developed partly under the influence of - and therefore resembles considerably - the latter, particularly the Mexican version. ${ }^{2}$ Both involve a special, prompt proceeding to effectuate fundamental entitlements.

In Mexico and Venezuela, the implement at issue as a general species seems to comprise its cousins of the habeas corpus family. In Brazil and perhaps in other localities across the region, however, it appears to exclude them. In actuality, its availability rides precisely on their unavailability along with that of the habeas data, ${ }^{3}$ which practically everywhere empowers one to access or correct personally pertinent information in the government's custody. ${ }^{4}$

On Brazilian soil, the primary habeas suit intimately intertwines in its history with those currently at stake. In counterpoint to them, though, it traveled from England in the nineteenth century. ${ }^{5}$ Judges seem to have relied on it to terminate infringements beyond those that might result in unlawful detentions. They appear to have gradually extended it to shelter all guaranteed personal liberties.

\footnotetext{
${ }^{2}$ See Hely lopes Meirelles, Mandando de Segurança 22 n.2 (2000); Carlos Alberto Menezes Direito, Manual do MANDAdo DE SeguranÇa 7 (1999).

${ }^{3}$ Const. art. 5(LXIX) (Braz.). See ARRUdA Alvim, MANDAdo De SEGURANÇa E Direito Público 351 (1995).

${ }^{4}$ CONST. art. 5(LXXII) (Braz.). See A PANORAMA OF BRAZILIAN LAW 389 n.5 (Jacob Dolinger \& Keith S. Rosenn eds., 1992). See ConsT. art. 43 (Arg.); Const. art. 130(I) (Bol.); L. 19.628, arts. 12-16 (Chile) (1999); CONST. art. 15 (Colom.); CONST. art. 92 (Ecuador); CONST. art. 31 (Guat.); ConST. art. 26(3) (Nicar.); L. 6 (Pan.) (2002); CONST. art. 135 (Para.); CONST. art. 200(3) (Peru); CoNST. art. 28 (Venez.).

${ }^{5}$ See generally Phanor J. Eder, "Habeas Corpus Disembodied: The Latin American Experience" in XXTH Century Comparative AND CONFlicts of LaW 463 (Kurt H. Nadelmann, Arthur von Mehren \& John N. Hazard eds., 1961); DIREITO, supra note 2, at 8.
} 
To detain these developments and reduce caseloads, the 1926 constitutional amenders resolved that it would lie "only where one [might] suffer[] imprisonment or illegal constraint in [the] freedom of locomotion." "To protect" those guaranties "left unprotected, ... Brazilians created a new juridical institution" combining the "effective" properties "of the Anglo-American . .. mandamus, prohibition, quo warranto, and injunction." historical ambition to weave an amply protective web around potential victims, Carlos Alberto Menezes Direito argues for an expansive and flexible construction. ${ }^{8}$

The surveyed contraption emerged in the 1934 instrument of governance. On January 16, 1936, it gained its statutorily detailed yardsticks. ${ }^{9}$ Alas, significant abridgments seem to have descended upon it with the authoritarian drifts around 1937. Fortunately, it appears to have regained its preceding status during the 1946 return of democracy. On December 31, 1951, a fresh enactment regulated the details from scratch. ${ }^{10}$ The current one of August 7, 2009, numbered 12.016, parametrized them anew. ${ }^{11}$

Updating language borrowed from its 1934 predecessor, ${ }^{12}$ the present 1988 charter speaks of shielding "immediately and clearly ascertainable rights." 13 It contemplates "official[s] or [the] agent[s] of an artificial person performing governmental duties" as "responsible for the [violative] illegality or abuse." 14 These phrases distill a couple of basic formal preconditions. They zero in (1) on selected safeguards, namely, those demonstrable through irrefutable printable evidence, and (2) on state action.

The highest justices of the land have viewed the first component within this duo as "a ... prerequisite for" admission. ${ }^{15}$ They have demanded "unequivocal proof" and deemed

\footnotetext{
${ }^{6}$ Eder, supra note 5, at 469. See also AlVIM, supra note 3, at 347-48.

${ }^{7}$ Kenneth L. KARSt \& KeIth S. Rosenn, LAW AND DEVElopment In LATIN AMERICA: A CASEBOOK (1975). See also DIREITO, supra note 2, at 9, 53; AlvIM, supra note 3, at 362-63.

${ }^{8}$ DIREITO, supra note 2, at 53-54.

${ }^{9}$ AlviM, supra note 3 , at 345 .

${ }^{10}$ Lei [L.] [Law] 1533 (Braz.) (1951).

${ }^{11}$ L. 12.016 (Braz.) (2009).

12 MeIRELles, supra note 2, at 35 n.2 (“A atual expressão direito líquido e certo substituiu a precedente da legislação criadora do mandado de segurança, direito certo e incontestável."); DIREITO, supra note 2, at 62 (1999); ALVIM, supra note 3, at 348.

${ }^{13}$ CONST. art. 5(LXIX) (Braz.) (Especificamente, “conceder-se-á mandado de segurança para proteger direito líquido e certo ....").

${ }^{14} I d$. ("[O] responsável pela ilegalidade ou abuso de poder [deve ser] autoridade pública ou agente de pessoa jurídica no exercício de atribuições do Poder Público . . . .”).

${ }^{15}$ Supremo Tribunal Federal [Sup. Trib. Fed.] [Supreme Court], Primeira Turma [First Chamber], Nov. 20, 1990, Recurso Extraordinário [Extraordinary Appeal] No. 117.936-8-Rio Grande do Sul [RE 117936 / RS] at
} 
Revista Eletrônica de Direito Processual - REDP.

Rio de Janeiro. Ano 15. Volume 22. Número 2. Maio a Agosto de 2021

Periódico Quadrimestral da Pós-Graduação Stricto Sensu em Direito Processual da UERJ

Patrono: José Carlos Barbosa Moreira (in mem.). ISSN 1982-7636. pp. 71-88

www.redp.uerj.br

it in itself neutral as to the pleas' eventual validities. ${ }^{16}$ Translated into United States lawyerly parlance, it must rule out a "genuine dispute as to any material fact"17 and may favor the endeavor or not.

Hely Lopes Meirelles comments that the case must center on the legality of the contested conduct. He adds that it should not revolve around the alleged factual circumstances. ${ }^{18}$ The Supreme Court has discoursed on these. It has insisted on their amenability to facial corroboration. ${ }^{19}$

The mechanism under the microscope covers entitlements such as those that a common-law summary judgment might sustain. ${ }^{20}$ Accordingly, it necessitates the ascertainability of their abrogation from the pled postulations or the complementary writings, like affidavits or certificates. ${ }^{21}$ The trier may not protractedly probe through witnesses, inspections, or experts. If she had to, she would have abort on the spot. ${ }^{22}$

The need for speedy satisfaction might furnish a justification for this requirement. Besides, it might undergird the temporal prioritization of this supplication for substantiation "over all other[s], except the habeas corpus." ${ }^{23}$ Direito underscores the aim of avoiding any gratuitous delaying. ${ }^{24} \mathrm{He}$ explains that determinative immediacy compels fixing the essential elements upfront for the definitive say. ${ }^{25}$

257 (Braz.) (on file with author) (Ementa [Summary]) (“O ‘direito líquido e certo,' pressuposto constitucional de admissibilidade do mandado se segurança, é requisito de ordem processual .....”).

${ }^{16} I d$. ("O 'direito líquido e certo' [atinge] à existência de prova inequívoca dos fatos em que se basear a pretensão do impetrante e não [à] procedência desta, matéria de mérito .....”).

${ }^{17}$ FED. R. CIV. P. 56.

${ }^{18}$ MeIRELLES, supra note 2, at 106.

${ }^{19}$ Sup. Trib. Fed., Plenário [Plenum], Nov. 7, 1990, Mandado de Segurança [Writ of Security] (Agravo Regimental [Internal Appeal]) No. 21.188-1-Distrito Federal [Federal District] [MS 21188 AgRg / DF] at 151 (Braz.) (on file with author) (Ementa). See also Sup. Trib. Fed., Primeira Turma, Aug. 20, 1991, Mandado de Segurança No. 21.098-2-Pará [MS 21098 / PA] at 301 (Braz.) (on file with author) (Ementa) ("The characteristic of only admitting literal, pre-constituted evidence, except for situations in which the law provides otherwise, goes to the essence of the writ of security's procedure.") ("É da essência do processo de mandado de segurança a característica de somente admitir prova literal pré-constituída, ressalvadas as situações excepcionais previstas em lei . ...”); Sup. Trib. Fed., Plenário, July 1, 2002, Mandado de Segurança No. 23.310-6-Rio de Janeiro [MS 23310 / RJ] at 476 (Braz.) (on file with author) (Ementa) ("[The] immediately and clearly ascertainable right ... presupposes non-contested facts supported by pre-constituted proof," and admits no "delay.”) (“[O] direito líquido e certo . . . pressupõe fatos incontroversos apoiados em prova préconstituída, não se admitindo dilação .....”).

${ }^{20}$ See, e.g., FED. R. CIV. P. 56.

${ }^{21}$ ALVIM, supra note 3, at 346, 349.

${ }^{22}$ MeIRELLES, supra note 2, at 36.

${ }^{23}$ L. 12.016 (Braz.) (2009), art. 20.

${ }^{24}$ DiReITO, supra note 2, at 64

${ }^{25}$ Id.; see id. at 69, 71. See also ALVIM (1995) at 349. 
Hence, the device on the table functions to vindicate instantly determinable guaranties. It relegates the vindication of others to its more mundane counterparts. Not surprisingly, neighboring nations call for a quick process too. ${ }^{26}$ Still, they seem not to bar non-documentary actualization.

In Brazil, a declination of the application might not entail prejudice. It might countenance a refiling by the applicant upon securing sufficient supportive documentation. The regulatory codification invites her to a "renewed" attempt upon an opening "dismissal" not entertaining "the merits." 27

Alternatively, she may lodge an ordinary pleading in the aftermath, hoping for an evidentiarily comprehensive probe. Stemming from uppermost echelons of the bench, Summation 304 stresses this prospect by remarking that a "denial . . does not constitute res judicata." It welcomes a succeeding commencement of "a suitable" cause, ${ }^{28}$ while obviously not foreclosing an abandonment altogether. These cogitations imply a distinction between a procedural and a substantive finding. They might grow in clarity through further explication.

Procedurally, the judicial intermediary adjudges documental determinability. At this juncture, it may either facially reject or recognize the claim. A rejection does not hinder the plaintiff from iterating or from heading in an ordinarily available direction. A recognition sheerly triggers an appraisal of meritoriousness.

Substantively, the adjudicator then reviews the documented contentions. She applies the applicable law in denying or granting the request. A no longer appealable resolution by her conceding the requested redress precludes supplementary debate before her or any of her colleagues on the definitively umpired controversy. ${ }^{29}$ Plainly, it blocks a reinstatement. Moreover, the claimants usually may not attempt alternate avenues on the affair or seek comparable condemnations. They may return to the courthouse solely when their newly litigated pretension does not entirely overlap with the original one.

As an illustration, a journalist who obtains the overturn of an officialized prior restraint may subsequently and separately recover monetary compensation in torts.

\footnotetext{
${ }^{26}$ See Const. art. 43 (Arg.); COnST. art. 129 (Bol.); Const. art. 86 (Colom.); Const. art. 72 (Dom. Rep.); Const. art. 44 (Pan.); ConsT. art. 134 (Para.); Const. art. 27 (Venez.).

${ }^{27}$ L. 12.016, art. 6(6) (Braz.) (2009) ("O pedido de mandado de segurança poderá ser renovado . . . , se a decisão denegatória não lhe houver apreciado o mérito.”).

${ }^{28}$ Sup. Trib. Fed., Plenário, Dec. 13, 1963, Súmula [Summation] 304 (Braz.) ("Decisão denegatória de mandado de segurança, não fazendo coisa julgada contra o impetrante, não impede o uso da ação própria.").

${ }^{29}$ MeIRELLES, supra note 2, at 101.
} 
Evidently, she could not have scored such a recovery during the foregoing round. Indeed, the top tribunal has discarded an award, in this setting, of "economic damages." ${ }^{30}$ It has predicated these on an embarkment upon "the appropriate ... procedure." 31

Brazilian scholars disagree on whether to treat a refusal on the substance as prejudicial. Meirelles replies to the query affirmatively, ${ }^{32}$ Arruda Alvim negatively. ${ }^{33}$ The forum of ultimate recourse has sided with the former. ${ }^{34}$ Nonetheless, it might have muddied the waters by narrowly zooming in on the repercussions on a successive stab of the same, not any, kind. ${ }^{35}$ The legislative wording might have supplementally contributed to the confusion. It addresses preclusion barely for non-material terminations of the litigation, not their presently apposite antitheses. ${ }^{36}$

Irrespective, a symmetrical preclusive impact would sound as sensible in this context as in that of summarily judging in Anglo-Saxon territory. It would advance efficiency and fairness. The adjudicative bodies at the forefront should have the last word upon fully refereeing on the file before them. Otherwise, they would have to go inefficiently through additional bouts and burden the defense unfairly by according its challenger another bite at the apple.

Illustratively, a woman might aver that her municipality sexually discriminated against her. During the inaugural phase, she would have to attest documentarily to the verifiability of her charges. Such an attestation would enable her to meet the requisite formally posited for the verification of admissibility.

Successively, an inquest on the matter would unfurl. Whenever the documents and germane principles authenticate an infraction, she will carry the day. In the alternative, her bid will fail. Under the proposed interpretation, she or her opponent may not thereafter refile, or file in a full-fledged manner, for discrimination.

\footnotetext{
${ }^{30}$ Sup. Trib. Fed., Plenário, Dec. 13, 1963, Súmula 271 (Braz.) (“Concessão de mandado de segurança não produz efeitos patrimoniais em relação a período pretérito . . ..”).

${ }^{31} I d$. (“[Os] efeitos patrimoniais . . . devem ser reclamados administrativamente ou pela via judicial própria.”).

${ }^{32}$ MEIRELLES, supra note 2, at 101-02.

${ }^{33}$ ALVIM, supra note 3, at 349-50, 355 (1995).

${ }^{34}$ Sup. Trib. Fed., Segunda Turma [Second Chamber], Apr. 15, 1996, Recurso Ordinário em Mandado de Segurança [Ordinary Appeal on a Writ of Protection] No. 22.367-1-Distrito Federal [RMS 22367 / DF], at 20 (Braz.) (on file with author).

35 The Summary states that "res judicata" forecloses "a new writ-of-security action," not that it produces such an effect vis-à-vis any suit on the same claim. $I d$. at 16 (“[A] coisa julgada material de decisão proferida em mandado de segurança anteriormente apreciado [torna] incabível nova ação mandamental.”).

${ }^{36}$ L. 12.016, art. 6(6) (2009).
} 
Nevertheless, the adjudicating organ might have to consider testimony to arbitrate her imputation. In such a scenario, it would have to dismiss against her non-prejudicially. In response, she might reengage upon reaping undisputed sworn statements that sufficiently settled what happened. Alternately, a standard trial with an ample evidentiary examination might follow. The flow chart in Figure 1 illustrates the entire sequence.

Figure 1

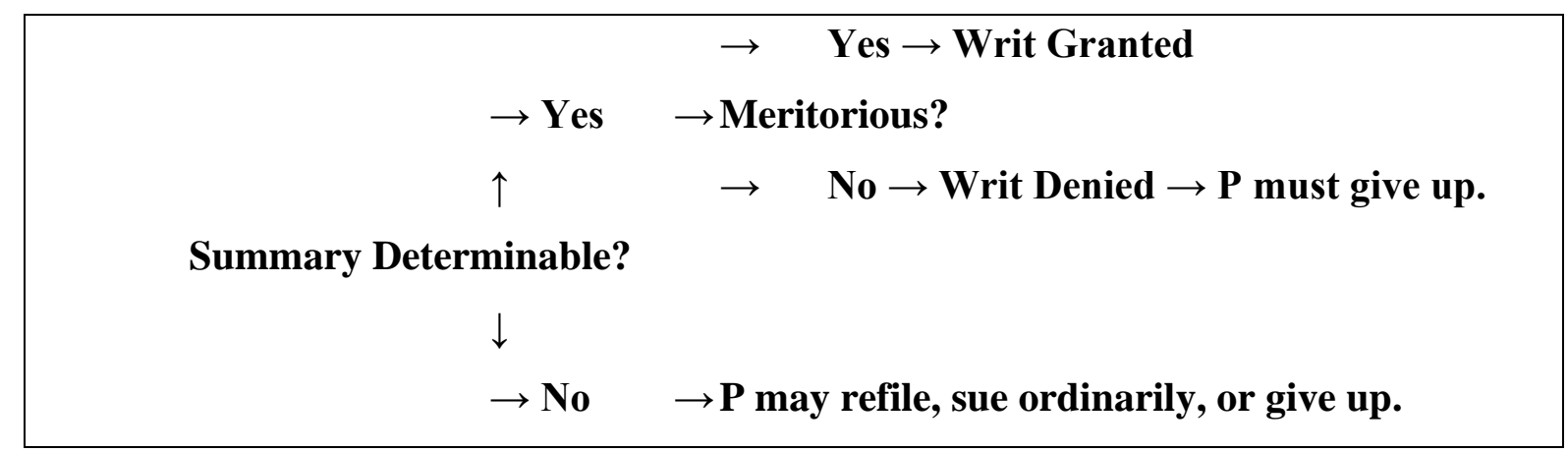

As noted, the Constitution contains another sine qua non: one's attentions must train on activities associated, explicitly or implicitly, with governing. Consistently, it restricts the category of those processable to "public" authorities "or" the proxies of a nongovernmental entity laboring in the name of the polity. ${ }^{37}$ The medium under analysis, in tandem with its analogues along certain other latitudes in Iberian America, ${ }^{38}$ may not target purely private violators. ${ }^{39}$ As previously observed, it diverges from that featured in most locations throughout the continent. ${ }^{40}$

In Brazil, an officer of the public prototypically finds herself on the receiving end. As Direito elucidates, she "sits in office" or accomplishes official "functions" and may

\footnotetext{
${ }^{37}$ CONST. (Braz.) art. 5 (LXIX) (“[Especificamente,] conceder-se-á mandado de segurança . . . quando o responsável pela ilegalidade ou abuso de poder for autoridade pública ou agente de pessoa jurídica no exercício de atribuições do Poder Público.”).

${ }^{38}$ See Ley de la Jurisdicción Constitucional [Constitutional Jurisdiction Act], L. 7135, art. 29 (Costa Rica) (1989); Ley de Procedimientos Constitucionales [Constitutional Procedures Act], art. 12 (El Sal.) (1960); Ley de Amparo, Exhibición Personal y de Constitucionalidad [Writ of Protection, Habeas Corpus, and Constitutionality Act], Decreto No. 1-86, art. 8 (Guat.) (1986); ConST. art. 183 (Hond.); ConsT. art. 103(I) (Mex.); Const. art. 188 (Nicar.); Const. art. 54 (Pan.).

${ }^{39}$ CONST. (Braz.) art. 5(LXIX).

${ }^{40}$ See CONST. art. 43 (Arg.); CONST. art. 128 (Bol.); Auto Acordado de la Excelentísima Corte Suprema sobre tramitación del Recurso de Protección [Supreme Court Decree on the Writ of Protection], arts. 3, 12 (Chile) (1977); CONST. art. 86 (Colom.); Const. art. 72 (Dom. Rep.); Const. art. 88 (Ecuador); Const. art. 134 (Para.); Const. art. 200(2) (Peru); Ley [L.] [Law] 16.011, art. 1 (Uru.) (1988); Ley Orgánica de Amparo sobre Derechos y Garantías Constitucionales [Organic Law on the Writ of Protection for Rights and Guaranties], art. 2 (Venez.) (1988).
} 
decide governmentally. ${ }^{41}$ Meirelles describes her as "invested with decision-making power within [her] legally assigned ambit of competence." 42 She might serve within an agency: paradigmatically as director ${ }^{43}$ or probably in other capacities to boot.

The constitutionalized definitional text draws a bead at legal contraventions and discretionary excesses. ${ }^{44}$ It spotlights commissions, jointly with omissions, ${ }^{45}$ amounting to threats or actual encroachments. ${ }^{46}$ The complainant may not move forward, though, while in possession of the possibility of adjectively stopping and questioning the comportment at bar without a deposit. ${ }^{47}$ A preponderance of Iberian American regimens would similarly coerce her to exhaust remedies. ${ }^{48}$ Contrariwise, a few would not. ${ }^{49}$

Through the Brazilian variant, one may not gainsay Congress on account of its legislation. Specifically, the premier adjudicatory institution nationwide has immunized laws "in the abstract." 50 It has commanded that such challenges occur through an unconstitutionality action, exercisable exclusively by select exercisers, such as the President, an executive parliamentary committee, the Republic's solicitor, governors, political parties, unions, or organizations. ${ }^{51}$

Consequently, a statutory proscription directed at the population at large would profit from immunity at the investigated junction. As prescribed, it would materially display

\footnotetext{
${ }^{41}$ DIREITO, supra note 2, at 26 (“É de entender-se autoridade pública como aquela que exerce um cargo ou uma função estatal em qualquer dos planos da federação e em qualquer dos poderes organizados, capaz de tomar decisões que manifestem a vontade do Estado.").

${ }^{42}$ Meirelles, supra note 2, at 32 ("Por autoridade entende-se a pessoa física investida de poder de decisão dentro da esfera de competência que lhe é atribuída pela norma legal.”).

${ }^{43}$ ALVIM, supra note 3 , at 359 .

${ }^{44}$ CONST. art. 5(LXIX) (Braz.). See ALVIM, supra note 3, at 346, 350.

${ }^{45}$ MeIRELlES, supra note 2, at 31, 33.

${ }^{46} I d$. at 99 .

${ }^{47}$ L. 12.016, art. 5(I) (Braz.) (2009). Nonetheless, the Supreme Court has held that in the case of an administrative omission, the writ of security might lie despite the possibility of an administrative appeal and stay. Súmula 429 (Supr. Ct.) (Plenary Chamber) (Braz.) (1964).

${ }^{48}$ See L. 16986, art. 2 (Arg.) (1966); L. 1836, art. 94 (Bol.) (1998); L. 12.016, art. 5(I) (Braz.) (2009); Decreto No. 2996, art. 1 (El Sal.) (1960); Decreto No. 1-86, art. 19 (Guat.) (1986); L. 49, art. 27(6) (Nicar.) (1988); Código Judicial [Judicial CODE] art. 2615(2) (Pan.); L. 23506, art. 27 (Peru) (1982); L. 16011, art. 2 (Uru.) (1988).

${ }^{49}$ See Decreto No. 2591, art. 9 (Colom.); L. 7135, art. 31 (Costa Rica) (1989); Ley de Amparo [Writ of Protection Act], art. 5 (Venez.) (1988).

${ }^{50}$ Sup. Trib. Fed., Plenário, Dec. 13, 1963, Súmula 266 (Braz.) ("Não cabe mandado de segurança contra lei em tese.").

${ }^{51}$ CONST. art. 103 (Braz.).
} 
Revista Eletrônica de Direito Processual - REDP.

Rio de Janeiro. Ano 15. Volume 22. Número 2. Maio a Agosto de 2021

Periódico Quadrimestral da Pós-Graduação Stricto Sensu em Direito Processual da UERJ

Patrono: José Carlos Barbosa Moreira (in mem.). ISSN 1982-7636. pp. 71-88

www.redp.uerj.br

"generality, impersonality, and abstraction." ${ }^{52}$ Patently, regulations may share these traits. If so, they would also qualify. ${ }^{53}$

Doubtless, a legislated norm might attain concretion. In particular, it might aim at singular subjects. Eventually, these could proceed against it. ${ }^{54}$ After all, it would sport administratively active "characteristics" and produce "concrete effects." ${ }^{55}$ For example, whenever the officialdom expropriates real-estate parcels to build highways, the owners may stand up against it.

Across the board ${ }^{56}$ with the mentioned notable exceptions of Argentina and Paraguay, ${ }^{57}$ the judge may not invalidate the pinpointed provisions. She may simply declare them circumstantially inapplicable. Notwithstanding, one may often have them proclaimed permanently or universally unconstitutional parallel or subsequent to, or as part of, the principal proceeding. ${ }^{58}$

As referenced earlier, the Supreme Court may exceptionally establish caselaw in some places. On the Mexican front, it needs a super-majority among its members and four previous identical consecutive holdings. ${ }^{59}$ Brazil, in turn, requires from it a two-thirds vote

\footnotetext{
52 Sup. Trib. Fed., Plenário, Aug. 21, 1996, [Federação Brasileira dos Sindicatos e Associações de Empresas de Asseio e Conservação - FEBRAC v. Presidente da República,] Mandado de Segurança No. 22.132-1-Rio de Janeiro [MS 22132 / RJ] at 185 (Braz.) (on file with author) (Ementa) (“[A] lei em tese ostenta características de generalidade, impessoalidade e abstração . . . ."); see also DIREITO, supra note 2, at 42 (1999) ("The writ may serve to attack an act that directly infringes upon a clear and certain right of the petitioner. What characterizes a law in the abstract is the generality of the command. If the challenged act is a non-individualized norm, the writ of security is inadmissible . . . Acts in the abstract are those that deal with general and impersonal situations, have a generic reach, and regulate hypotheses that are contemplated abstractly.") ("O writ há de atacar o ato que, diretamente, vulnera o Direito líquido e certo do impetrante. O que caracteriza a lei em tese é a generalidade do comando; desde que ato atacado seja uma norma não individualizada, é incabível o mandado de segurança. ... Atos em tese são os que dispõem sobre situações gerais e impessoais, têm alcance genérico e disciplinam hipóteses que neles se acham abstratamente previstas.”).

${ }_{53}$ ALVIM, supra note 3, at 351-52.

${ }^{54} \mathrm{Id}$. at $351-52,358$.

${ }^{55}$ Sup. Trib. Fed., Plenário, FEBRAC v. Presidente da República, MS 22132 / RJ, at 194 (Braz.) (on file with author) ("É certo que, quando o ato normativo é puramente formal, apresentando, sob o ponto de vista material, características de ato administrativo, de efeitos concretos, . . pode ele ser objeto do mandado de segurança."). 56 See, e.g., Decreto No. 2591, art. 29(6) (Colom.) (1991); Decreto No. 2996, art. 81 (El Sal.) (1997); Decreto No. 1-86, art. 49(a) (Guat.) (1986); Ley de Amparo, art. 47 (Hond.) (1936); ConST. art. 107(II) (Mex.); L. 44, art. 44 (Nicar.) (1988); L. 23506, art. 3 (Peru) (1982); Ley de Amparo, art. 3 (Venez.) (1988).

${ }^{57}$ Const. art. 43 (Arg.); Código Procesal Civil art. 582 (Para.) (1988).

${ }^{58}$ See L. 1836, arts. 58(II), 65 (Bol.) (1998); ConST. art. 241 (Colom.); L. 7135, art. 48 (Costa Rica) (1989); Const. art. 185(1) (Dom. Rep.); ConST. art. 183 (El Sal.); Decreto No. 1-86, art. 123 (Guat.) (1986); CONST. art. 185 (Hond.); CONST. art. 187 (Nicar.); CONST. art. 206(1) (Pan.); Ley Orgánica del Tribunal Supremo de Justicia [Organic Law on the Supreme Court], art. 33 (Venez.) (2010).

${ }^{59}$ Ley de Amparo, arts. 192, 193 (Mex.) (1936). Article 43 of the Guatemala's Writ of Protection, Habeas Corpus, and Constitutionality Act, in turn, establishes the following: "The Constitutional Court's interpretation of constitutional and legal norms in three consecutive decisions establishes legal doctrine that other tribunals
} 
"after reiterated prior" pronouncements "on point," upon division among its hierarchical inferiors, and in situations of "serious legal uncertainty." 60

On Brazilian terrain, anybody affected may sometimes set her sight on "final . . . dispositions [hailing from a courtroom and] not subject to suspension." ${ }^{61}$ She must show them susceptible to cause "irreparable harm." 62 Needless to say, a showing of documentary demonstrability must accompany that of a delay's susceptibility to harm irreparably.

Once again, the accessibility of review and stay would forestall this option. ${ }^{63}$ After all, it would presumptively prevent irreparability. Parenthetically, interlocutory decrees might not boast appealability. When so, they would turn into reviewable through the scrutinized channel. ${ }^{64}$ Their gainsayers have commonly embarked upon this route against them. ${ }^{65}$

The bench has seemingly tended to handle such quests in whatever form as extraordinary motions to paralyze the ongoing process. Ergo, it has ostensibly dictated a simultaneous pursuit of any regular appeal at hand. Several commentators have objected to this take. ${ }^{66}$ They have maintained that an independent litigation launches, obviating such regularly pursued path. ${ }^{67}$ In any event, Direito cautions that the writ may not challenge rebuffs of an antecedent one, even if an appellate intermediation would not halt their execution. ${ }^{68}$ Through this caution, he may be trying to preempt an endless recurrence of death and transfiguration.

must respect." Decreto No. 1-86, art. 43 (Guat.) (1986) ("La interpretación de las normas de la Constitución y de otras leyes contenidas en las sentencias de la Corte de Constitucionalidad, sienta doctrina legal que debe respetarse por los tribunales al haber tres fallos contestes de la misma Corte.”).

${ }^{60}$ CONST. art. 103(A) (Braz.).

${ }^{61}$ Sup. Trib. Fed., Segunda Turma, June 13, 1980, Recurso Extraordinário No. 90.536-3- São Paulo [RE 90536 / SP] at 742 (Braz.) (on file with author) (Ementa) ("Ato judicial [é] passível de recurso . . . no caso . . . da não suspensividade do recurso e da ilegalidade do ato impugnado ...."); see also DIREITO, supra note 2, at 49. See DIREITO, supra note 2, at 58.

${ }^{62}$ Id. ("Ato judicial [é] passível de recurso . . . no caso em que . . . do ato impugnado . . . advenha dano irreparável, cabalmente demonstrado.").

63 "The writ of security," according to the Supreme Court's Summation 267, "shall not lie against judicial acts subject to appeal or modification." Sup. Trib. Fed., Plenário, Dec. 13, 1963, Súmula 267 (Braz.) ("Não cabe mandado de segurança contra ato judicial passível de recurso ou correição.").

${ }^{64}$ DIREITO, supra note 2, at 57.

${ }^{65}$ Id. Direito cites, as an example, a decision of the Fourth Chamber of the Superior Court. Id. at 57-58 (citing RSTJ 24/218).

${ }^{66} \mathrm{Id}$. at 54 .

${ }^{67} I d$.

${ }^{68} \mathrm{Id}$. at 57. 
In addition, those charged with "delegated" $"$ tasks, directly or in the service of semi-publicly or privately founded corporations, ${ }^{70}$ expose themselves to prosecution. Exemplarily, they might work for a company administering transportation, electricity, or education. Manifestly, disproving the delegation in question would allow them to escape responsibility from the get-go.

At any rate, the suitor may strictly oppose their deportment as delegates. She must track "the nature of the act." illegally parked cars would respond for offenses arising during a tow. It would not risk liability while repairing vehicles. Naturally, the exact scope of the answerability might defy those who would have to define it. In consequence, it might generate polemics between the disputants around its definition.

Pertinently, the adjudication may not assail daily "commercially managerial" operations. ${ }^{72}$ In all probability, it may not check the management of employees. Presumably, such a check may unreel through other means.

Sparingly evoking the focal adjective prescriptions through a single sentence, the constitutionally framed strictures do not specify who enjoys standing. They scantly suggest that it might rest in the organizational or individual holder of the defended right. Their codified complements announce that when "various" candidates fit the bill, "any one of them may" step up. ${ }^{73}$ Furthermore, they sketch how the whole procedure unfolds.

"The initial petition" fires off the lawsuit. ${ }^{74}$ It must articulate its specific solicitation and attach the relevant records. The petitioner may judicially wrest these from an opposite number in control of them and unwilling to hand them over ${ }^{75}$ She must self-evidently

\footnotetext{
${ }^{69}$ Sup. Trib. Fed., Plenário, Dec. 12, 1969, Súmula 510 (Braz.) ("Praticado o ato por autoridade, no exercício de competência delegada, contra ela cabe o mandado de segurança ou a medida judicial.").

${ }^{70}$ L. 12.016, art 1(1) (Braz.) (2009). The statute subsumes "political parties" under the bodies that the defendants may serve. Id. ("Equiparam-se às autoridades . . . os representantes ou órgãos de partidos políticos ....").

${ }^{71}$ DIREITO, supra note 2, at 30 ("O critério utilizado para decidir é o da natureza do ato.”).

${ }^{72}$ L. 12.016, art 1(2) (Braz.) (2009) ("Não cabe mandado de segurança contra os atos de gestão comercial praticados pelos administradores de empresas públicas, de sociedade de economia mista e de concessionárias de serviço público.”).

${ }^{73} I d$. art. 1(3) ("Quando o direito ameaçado ou violado couber a várias pessoas, qualquer delas poderá requerer o mandado de segurança.").

${ }^{74} I d$. art. 6 ("A petição inicial . . . será apresentada . . . .").

${ }^{75} \mathrm{Id}$. art. 6(1).
} 
Revista Eletrônica de Direito Processual - REDP.

Rio de Janeiro. Ano 15. Volume 22. Número 2. Maio a Agosto de 2021

Periódico Quadrimestral da Pós-Graduação Stricto Sensu em Direito Processual da UERJ

Patrono: José Carlos Barbosa Moreira (in mem.). ISSN 1982-7636. pp. 71-88

www.redp.uerj.br

discover their existence before the wrest and apparently cannot capitalize on anything reminiscent of discovery for such purposes.

Her libel must land on the docket within about tetrad of months of her knowledge of the decried outrage. ${ }^{76}$ Against "an omission," the clock starts ticking on the date in which the supposed omitted obligation toward her becomes due. ${ }^{77}$ In the absence of a "time limit" for performance or in the teeth of a "continuing" violation, she may commence anytime. ${ }^{78}$ On an appealable abridgement, the statute of repose begins its run after she appeals or misses the deadline to do so. By the way, it does not alter its course upon an entreaty to the answerable administrators for "reconsideration."79

Promptly after noticing any reparable defect in the complaint, the trier must afford the filers ten days to amend. Upon instead reckoning such an amendment as unnecessary, she must assess sua sponte whether a menace or impingement (1) has likely transpired and (2) must cease in the meantime to avert irreversible injury to them. ${ }^{80}$ This assessment "lies within [her] discretion." ${ }^{81}$ As just insinuated, she must gauge their likelihood of success on the substance and the risk of their prayed-for relief "degrading into pointlessness" after the fall of the gavel. ${ }^{82}$

\footnotetext{
${ }^{76}$ Id. art. 23. See ALVIM, supra note 3, at 353.

${ }^{77}$ Sup. Trib. Fed., Primeira Turma, June 27, 1969, Recurso em Mandado de Segurança [Appeal on Writ of Protection] No. 18.387-Minas Gerais [RMS 18387 / MG] at 305 (Braz.) (on file with author) (Ementa) ("Se marca a lei prazo para a pratica do ato, após o decurso desse prazo começa a omissão a violar o direito do impetrante, $\operatorname{logo}$, a contar do fim daquele prazo, começou a ilegalidade por omissão, devendo-se dai contar o prazo de 120 dias para ingresso em juízo.").

${ }^{78}$ Sup. Trib. Fed., Primeira Turma, Oct. 30, 2012, Agravo Regimental no Recurso Extraordinário com Agravo [Regular Interlocutory Appeal on an Extraordinary Appeal with Interlocutory Appeal] No. 696.434-Bahia [ARE 696434 AGR / BA] at 6 (Braz.) (on file with author) (Relatório) (quoting the acórdão recorrido [appealed holding]) ("[Finalmente], em se tratando de ato omissivo, sem prazo certo para ser executado, inaplicável o prazo certo para ser executado, [é] inaplicável o prazo de decadência ."); Sup. Trib. Fed., Primeira Turma, Mar. 23, 2011, Agravo Regimental no Recurso Extraordinário [Regular Interlocutory Appeal on an Extraordinary Appeal] No. 547.130-Distrito Federal [RE 547130 AgR / DF] at 63 (Braz.) (on file with author) (citing the jurisprudência [caselaw] of the Superior Tribunal of Justice) ("[Assim], em se tratando de mandado de segurança contra omissão . ..., não há que se falar em decadência de direito. Com efeito, cuida-se de ato omissivo continuado, que se renova seguidamente.").

${ }^{79}$ Sup. Trib. Fed., Plenário, Aug. 7, 1964, Súmula 430 (Braz.) ("Pedido de reconsideração na via administrativa não interrompe o prazo para o mandado de segurança").

${ }^{80}$ L. 12.016, art. 7(III) (Braz.) (2009). See ALVIM, supra note 3, at 363.

${ }^{81}$ Sup. Trib. Fed., Plenário, Apr. 26, 1991, Mandado de Segurança (Agravo Regimental) No. 21.206-3-Distrito Federal [MS $21206 \mathrm{AgRg}$ / DF] at 17 (Braz.) (on file with author) ("A atuação do magistrado ocorre no campo da livre discrição e independentemente de pedido.").

${ }^{82}$ Id. ("Aprecia as circunstâncias reveladas pela inicial e, verificando o concurso das condições legais relevância do pedido e possibilidade de a concessão da segurança vir a cair no vazio — determina a suspensão do ato.").
} 
Upon positive determinations by her on these factors, a precautionary measure must ensue. Theoretically, it should permit her to appraise the allegations deliberately and effectively. ${ }^{83}$ Anyway, she must retroactively suspend it to the extent possible after conclusively casting them aside. ${ }^{84}$

Apropos, it recalls United States' temporary restraining orders. ${ }^{85}$ Like it, these may issue without the issuer alerting or hearing the adversary in advance. ${ }^{86}$ On the other side of the scale, it may exceed them in extension. While they automatically expire after ten days., ${ }^{87}$ it may remain in force throughout. ${ }^{88}$ Additionally, those enjoined may not interlocutorily counter it. ${ }^{89}$ Nor may they pursue the writ under perusal against it. ${ }^{90}$ Appositely, the Venezuelan top tribunal has struck down such unreviewability for unconstitutionally occasioning "defenselessness." 91

In Brazil, the adjudicator must have the defendant generally notified in succession. She must assure his receipt of the summons and denunciation against him, plus the auxiliary papers. He must answer within ten days. ${ }^{92}$ The Public Ministry must opine before her within that very period. ${ }^{93}$

Next, she must confirm the assessibility of the accusations on their face. Upon her confirmation of the fulfillment of this decisive condition, she shifts to the stage of

\footnotetext{
${ }^{83}$ DiREITO, supra note 2, at 21.

${ }^{84}$ Sup. Trib. Fed., Plenário, Aug. 7, 1964, Súmula 405 (Braz.).

${ }^{85}$ See FED. R. CIV. P. 65.

${ }^{86} \mathrm{Id}$.

${ }^{87} \mathrm{Id}$.

${ }^{88}$ L. 12.016, art. 7(III)(iii) (Braz.) (2009). Arruda Alvim notes that in ordinary cases the preliminary judgment lasts as long as the trial and argues that treating the writ of security differently would neither stand to reason nor pass constitutional muster. ALVIM, supra note 3, at 354, 356.

${ }^{89}$ Sup. Trib. Fed., Plenário, May 26, 1993, Mandado de Segurança (Agravo Regimental) No. 21.676-1-Paraná [MS $21676 \mathrm{AgRg} / \mathrm{PR}$ ] at 130 (Braz.) (on file with author) (Ementa).

${ }^{90}$ Sup. Trib. Fed., Plenário, June 5, 1985, Reclamação [Reclamation] No. 176-8-São Paulo [RCL 176 / SP] at 12 (Braz.) (on file with author) (Ementa).

${ }^{91}$ Sup. Ct.de J., Pleno, Apr. 16, 1996, Expediente No. 644, at 7 (Part III) (Venez.) (on file with author) (“[E]s evidente que estamos ante una grosera y flagrante indefensión, ya que el nombrado artículo 22 [de la Ley Orgánica de Amparo sobre Derechos y Garantías Constitucionales], choca abierta y directamente con la 'defensa [como] derecho' . . ..”') (quoting Const. art. 68 (Venez.) (1961)); see also Trib. Sup. de J., Sala Constitucional, June 3, 2014, Sentencia 609, Expediente No. 11-0306, at 20 (Venez.) (on file with author) (quoting Trib. Sup. de J., Sala Constitucional, July 16, 2013, Sentencia 993, Expediente No. 13-0230, at 21-22 (Venez.) (on file with author)) ("[An] oral hearing in the protective procedure has become routine to uphold the right of defense and hear the parties or interested third parties.") ("[L]a celebración de la audiencia oral en el procedimiento de amparo se hizo rutinaria para hacer prevalecer el derecho de la defensa y oír a las partes y a los terceros interesados.").

${ }^{92}$ L. 12.016, art. 7(I) (Braz.) (2009).

${ }^{93}$ Id. art. 12.
} 
"ascertainment." 94 This shift obligates her to determine whether the accusatory postures hold, betokening a transgression. Incidentally, she may not award the usual attorney's fees to the prevailing party. ${ }^{95}$

Meirelles portrays the judgment as self-executing. ${ }^{96} \mathrm{He}$ might mean that a victorious supplicant need not execute it afterward or apart. Anyhow, she may encounter difficulties in collecting her repair against an uncooperative debtor. To Alvim, the judiciary wields "no efficient" weapon to uphold its settlement. ${ }^{97}$ Frequently, it depends on the executive for such enforcement. ${ }^{98}$

As one might expect, the litigants may appeal. ${ }^{99}$ So may the publicly ministerial lawyers or anyone somehow impacted. ${ }^{100}$ The appeal normally does not stay the decision.

As already affirmed, the latter does not possess precedential ramifications overall. As a result, it may influence but does not control future ones. These may supervene at odds with it and without overruling, lamenting, distinguishing, or alluding to it. Concededly, this approach appears to predominate in all domains across the tradition.

\footnotetext{
${ }^{94}$ Sup. Trib. Fed., Plenário, Nov. 7, 1990, Mandado de Segurança (Agravo Regimental) No. 21.188-1-Distrito Federal [Federal District] [MS $21188 \mathrm{AgRg} / \mathrm{DF}$ ] at 156 (Braz.) (on file with author) ("Se os fatos estão comprovados, de plano, está satisfeito o requisito que autoriza o ajuizamento do mandado de segurança. Seguirse-á, então, a fase que eu chamaria de acertamento . . ..").

95 Compare L. 12.016, art. 25 (Braz.) (2009) ("The writ of security procedure does not allow an award of attorney's fees . . . .") ("Não cabem, no processo de mandado de segurança . . . a condenação ao pagamento dos honorários advocatícios ... .”), with CD. PRO. CIV., L. 13105 (Braz.) (2015), art. 85 ("The judgment shall condemn the defeated party to pay her prevailing opponent's attorney's fees.") (“A sentença condenará o vencido a pagar honorários ao advogado do vencedor.”).

96 MEIRELLES, supra note 2, at 97, 98.

97 See AlviM, supra note 3, at 356 (§ XXIII) (“Os quadros do nosso Direito Positivo, todavia, não dão ao Judiciário um instrumental tão eficiente para realizar efetivamente a eficácia duma sentença, quando proferida contra o Poder Público, senão por maneiras indiretas.").

${ }^{98}$ See ALVIM, supra note 3, at 356.

${ }^{99}$ L. 12.016, art. 18 (Braz.) (2009).

${ }^{100}$ MeIRELLES, supra note 2, at 99.
} 


\section{BIBLIOGRAPHIC REFERENCES}

MEIRELLES, Hely Lopes. Mandado de Segurança: ação popular, ação civil pública, mandado de injunção, habeas data, ação direta de inconstitucionalidade e ação declaratória de constitucionalidade. 22a edição, n.2. São Paulo, Malheiros, 2000.

DIREITO, Carlos Alberto Menezes. Manual do mandado de segurança. $3^{a}$ edição. Rio de Janeiro, Renovar, 1999.

ALVIM, Eduardo Arruda. Mandado de segurança e direito público. São Paulo, Revista dos Tribunais, 1995.

DOLINGER, Jacob; ROSENN, Keith S.. A panorama of brazilian law. Published jointly by the North-South Center and Editora Esplanada Ltda: 1992.

EDER, Phanor J., "Habeas Corpus Disembodied. The Latin American Experience”, en XXth Century Comparative and Conflicts Law. Legal Essays in Honor of Hessel E. Yntema, edited by Kurt H. Nadelmann, Arthur T. von Mehren and John N. Hazard on behalf of the Board of Editors of the American Journal of Comparative Law, Leyden, A. W. Sythoff, 1961.

KARST, Kenneth L.; ROSENN, Keith S. Law and Development in Latin America: A Case Book. Berkeley, University Df California Press, 1975

\section{LEGISLATION AND DECISIONS OF BRAZILIAN COURTS}

Auto Acordado de la Excelentísima Corte Suprema sobre tramitación del Recurso de Protección [Supreme Court Decree on the Writ of Protection], arts. 3, 12 (Chile) (1977);

CONST. (Hond.).

CONST. (Mex.).

CONST. (Nicar.);

CONST. (Pan.).

CONST. (Arg.).

CONST. (Bol.);

CONST. (Colom.); 
CONST. (Dom. Rep.);

CONST. (Ecuador);

CONST. (Para.);

CONST. (Peru);

CONST. (El Sal.);

CÓDIGO JUDICIAL [JUDICIAL CODE] art. 2615(2) (Pan.);

CÓDIGO PROCESAL CIVIL art. 582 (Para.) (1988).

Decreto No. 2996, art. 1 (El Sal.) (1960);

Decreto No. 1-86, art. 19 (Guat.) (1986);

Decreto No. 2591, art. 29(6) (Colom.) (1991);

Decreto No. 2996, art. 81 (El Sal.) (1997);

Decreto No. 1-86, art. 49(a) (Guat.) (1986);

L. 12.016 (Braz.) (2009).

L. 16986, art. 2 (Arg.) (1966);

L. 1836, art. 94 (Bol.) (1998);

L. 12.016, art. 5(I) (Braz.) (2009);

L. 49, art. 27(6) (Nicar.) (1988);

L. 23506, art. 27 (Peru) (1982);

L. 16011, art. 2 (Uru.) (1988).

L. 7135, art. 31 (Costa Rica) (1989);

L. 44, art. 44 (Nicar.) (1988);

L. 23506, art. 3 (Peru) (1982);

L. 1836, arts. 58(II), 65 (Bol.) (1998);

L. 7135, art. 48 (Costa Rica) (1989);

Ley [L.] [Law] 16.011, (Uru.) (1988);

Ley de la Jurisdicción Constitucional [Constitutional Jurisdiction Act], L. 7135, art. 29.

Ley de Amparo, art. 47 (Hond.) (1936);

Ley de Amparo, art. 3 (Venez.) (1988).

Ley Orgánica del Tribunal Supremo de Justicia [Organic Law on the Supreme Court], art. 33 (Venez.) (2010)

Ley de Amparo, arts. 192, 193 (Mex.) (1936). 
Supremo Tribunal Federal [Sup. Trib. Fed.] [Supreme Court], Primeira Turma [First Chamber], Nov. 20, 1990, Recurso Extraordinário [Extraordinary Appeal] No. 117.936-8-Rio Grande do Sul [RE 117936 / RS] at 257 (Braz.) (on file with author) (Ementa [Summary]).

Sup. Trib. Fed., Plenário [Plenum], Nov. 7, 1990, Mandado de Segurança [Writ of Security] (Agravo Regimental [Internal Appeal]) No. 21.188-1-Distrito Federal [Federal District] [MS $21188 \mathrm{AgRg} / \mathrm{DF}]$ at 151 (Braz.) (on file with author) (Ementa). See also Sup. Trib. Fed., Primeira Turma, Aug. 20, 1991, Mandado de Segurança No. 21.098-2-Pará [MS 21098 / PA] at 301 (Braz.) (on file with author) (Ementa).

Sup. Trib. Fed., Plenário, July 1, 2002, Mandado de Segurança No. 23.310-6-Rio de Janeiro [MS 23310 / RJ] at 476 (Braz.) (on file with author) (Ementa).

Sup. Trib. Fed., Plenário, Dec. 13, 1963, Súmula [Summation] 304 (Braz.).

Sup. Trib. Fed., Plenário, Dec. 13, 1963, Súmula 271 (Braz.).

Sup. Trib. Fed., Segunda Turma [Second Chamber], Apr. 15, 1996, Recurso Ordinário em Mandado de Segurança [Ordinary Appeal on a Writ of Protection] No. 22.367-1Distrito Federal [RMS 22367 / DF], at 20 (Braz.).

Sup. Trib. Fed., Plenário, Dec. 13, 1963, Súmula 266 (Braz.).

Sup. Trib. Fed., Plenário, Aug. 21, 1996, [Federação Brasileira dos Sindicatos e Associações de Empresas de Asseio e Conservação - FEBRAC v. Presidente da República,] Mandado de Segurança No. 22.132-1-Rio de Janeiro [MS 22132 / RJ] at 185 (Braz.).

Sup. Trib. Fed., Plenário, FEBRAC v. Presidente da República, MS 22132 / RJ, at 194 (Braz.).

Sup. Trib. Fed., Segunda Turma, June 13, 1980, Recurso Extraordinário No. 90.536-3- São Paulo [RE 90536 / SP] at 742 (Braz.).

Sup. Trib. Fed., Plenário, Dec. 12, 1969, Súmula 510 (Braz.) .

Sup. Trib. Fed., Primeira Turma, June 27, 1969, Recurso em Mandado de Segurança [Appeal on Writ of Protection] No. 18.387-Minas Gerais [RMS 18387 / MG] at 305 (Braz.)

Sup. Trib. Fed., Primeira Turma, Oct. 30, 2012, Agravo Regimental no Recurso Extraordinário com Agravo [Regular Interlocutory Appeal on an Extraordinary Appeal with Interlocutory Appeal] No. 696.434-Bahia [ARE 696434 AGR / BA] at 6 (Braz.)

Sup. Trib. Fed., Plenário, Aug. 7, 1964, Súmula 430 (Braz.) 
Sup. Trib. Fed., Plenário, Apr. 26, 1991, Mandado de Segurança (Agravo Regimental) No. 21.206-3-Distrito Federal [MS 21206 AgRg / DF] at 17 (Braz.).

Sup. Trib. Fed., Plenário, May 26, 1993, Mandado de Segurança (Agravo Regimental) No. 21.676-1-Paraná [MS 21676 AgRg / PR] at 130 (Braz.).

Sup. Trib. Fed., Plenário, June 5, 1985, Reclamação [Reclamation] No. 176-8-São Paulo [RCL 176 / SP] at 12 (Braz.).

Sup. Ct.de J., Pleno, Apr. 16, 1996, Expediente No. 644, at 7 (Part III) (Venez.).

Sup. Trib. Fed., Plenário, Nov. 7, 1990, Mandado de Segurança (Agravo Regimental) No. 21.188-1-Distrito Federal [Federal District] [MS 21188 AgRg / DF] at 156 (Braz.).

Trib. Sup. de J., Sala Constitucional, June 3, 2014, Sentencia 609, Expediente No. 11-0306, at 20 (Venez.). 